\title{
The Remler M2000 semi-automatic blood pressure recorder
}

Sir,

The Remler M2000 semi-automatic blood pressure recorder together with the $\mathrm{M} 3000$ decoder have recently become available and provide a method of obtaining home blood pressure readings. While using it, however, we gained the impression that it recorded substantially higher blood pressures than those measured using conventional sphygmomanometers in our clinic. We, therefore, tested the accuracy and reliability of the Remler system against the London School of Hygiene (LSH), and Hawksley Random Zero (RZS) sphygmomanometers, as well as direct intra-arterial readings, together with a general practice based evaluation.

Firstly, we connected a Remler recorder and a conventional mercury manometer via a t-tube to a single cuff wrapped round a bottle. We were able to show that the calibration marks on the Remler print-outs were exactly at the correct level of blood pressure read on the mercury manometer.

The results of our comparison of Remler recordings with those with the $\mathrm{LSH}, \mathrm{RZS}$, and intra-arterial blood pressure levels are shown in the Table. The LSH study was taken with blood pressures in 14 subjects measured in the same arm as the Remler, with a t-tube attachment as above. The RZS study was conducted along similar lines to that of Ramsay et al. (1977); blood pressures being measured in opposite arms by two observers

Table Mean systolic and diastolic blood pressure measured using Remler M2000 recorder in comparison with London School of Hygiene, Random Zero sphygmomanometer, and direct intra-arterial readings

\begin{tabular}{llc}
\hline & $\begin{array}{l}\text { Blood pressure } \\
\text { Systolic }\end{array}$ & $\begin{array}{c}(\mathrm{mmHg}) \\
\text { Diastolic } \\
\text { Phase 5 }\end{array}$ \\
\hline Remler & $166 \cdot 5$ & $115 \cdot 1$ \\
LSH & $159 \cdot 1^{\star}$ & $104 \cdot 7^{\star}$ \\
Remler & $145 \cdot 6$ & $93 \cdot 4$ \\
RZS & $137 \cdot 2 \dagger$ & $85 \cdot 3^{\star}$ \\
Remler & $170 \cdot 9$ & $107 \cdot 0$ \\
Intra-arterial & $159 \cdot 5 \dagger$ & $80 \cdot 9 \star$ \\
\hline
\end{tabular}

$\star P<0.001 ; \quad+P<0.01$. who alternated machines. There was no tendency for differing blood pressure estimations between arms or between observers, but a strong tendency to higher readings from the Remler recorder. These differences could not be accounted for by systematic tendencies to record blood pressures at the fourth or fifth diastolic phases. The discrepancy between Remler recordings and intra-arterial blood pressures measured in opposite arms was even greater.

We have further tested the reliability of the Remler machine in general practice, by attempting to obtain 544 home blood pressure readings on 28 microcassettes in 9 well-motivated patients. At decoding, only 276 readings $(50.7 \%)$ could be interpreted from the print-outs. The most frequent reason for inability to obtain readings resulted from calibration artefacts obscuring the pulse beats, and not from failure to obtain sufficiently large pulse beats by unsatisfactory attachment of the microphone over the brachial artery.

While the Remler blood pressure measuring system has many attractions, and further development should be encouraged, we cannot recommend its use in view of the consistent overreading and unreliability.

D. G. Beevers ${ }^{1}$ and C. A. Bloxham, University Department of Medicine, Dudley Road Hospital, Birmingham;

C. I. Backhouse, General practice, East Horsley, Surrey;

C. C. Lim, Bristol Myers Co Ltd., Windsor;

R. D. S. Watson, University Department of Cardiology, East Birmingham Hospital, Birmingham.

${ }^{1}$ Further details of our results can be obtained from D. G. B.

\section{Reference}

Ramsay, L. E., Nicholls, M. G., and Boyle, P. (1977). The Elag-Koln automatic blood pressure recorder: a clinical appraisal. British Heart fournal, 39, 795-798. 